\title{
Výuka s interaktivní tabulí versus tradiční výuka v primární škole
}

Education with an interactive whiteboard versus traditional education at primary school

\author{
Švrčinová Veronika
}

\begin{abstract}
Abstrakt: Př́spěvek předkládá výsledky předvýzkumu disertační práce. Předvýzkum je zaměřen na srovnání výsledků didaktického testu z matematiky, který byl uskutečněn ve třídě, která pracuje s interaktivní tabulí, a ve třídě vyučované tradičními metodami. Cílem předvýzkumu disertační práce bylo zjistit, zda konstantní používání interaktivní tabule ve výuce matematiky na 1 . stupni ZŠ může ovlivnit výsledky žáků. Výzkumný vzorek tvořili žáci 1. a 2. tř́idy primární školy. V předvýzkumu jsme použili U-test Manna a Whitneyho.
\end{abstract}

Klíčová slova: didaktický test, informační gramotnost, interaktivní tabule, kurikulární reforma, U-test Manna a Whitneyho

\begin{abstract}
The paper presents the results of the dissertation pre-research. Pre-research focuses on the comparison of the results of the didactic test in mathematics, which was implemented in the class that works with the interactive whiteboard, and in a class taught by traditional methods. The aim of the dissertation pre-research was to determine whether the constant use of the inetarctive whiteboard in teaching mathematics at primary school may affect the pupils results. The research sample consisted of $1^{\text {st }}$ and $2^{\text {nd }}$ class pupils of primary school. We used Mann and Whitney U-test in the pre-research.
\end{abstract}

Keywords: didactic test, information literacy, interactive whiteboards, a curricular reform, Mann and Whitney U-test

\section{1 Úvod}

Náš svět se mění a informační a komunikační technologie (dále jen ICT) je centrem tohoto dění, je jedním z hnacích motorů globální revoluce, která zasáhla rovněž vzdělávání a výchovu. Český školský systém se snaží adaptovat na nové podněty v edukační sféree, a tak není výjimkou, že zařazování interaktivních tabulí do výchovně vzdělávacího procesu je realitou. Český výchovně vzdělávací proces provázejí interaktivní tabule již deset let, ve světě má využívání těchto moderních dotykově senzitivních zařízení mnohem delší tradici. Společnost SMART Technologies Inc. představila světu interaktivní tabule již v roce 1991. Dnes jsou tyto moderní interaktivní systémy rozšsiřeny do 70 zemí světa. Jak uvádí portál Veškole.cz, za čtvrt roku bylo prodáno ve světě přes 250000 interaktivních tabulí. Interaktivní tabule tak intenzivně zasahují do vzdělávacích systémů. 


\section{Interaktivní výuka}

Implementace ICT do výuky je v korespondenci se současnou kurikulární reformou. RVP ZV přímo vyděluje vzdělávací oblast Informační a komunikační technologie, která „umožňuje všem žákům dosáhnout základní úrovně informační gramotnosti - získat elementární dovednosti v ovládání výpočetní techniky a moderních informačních technologií, orientovat se ve světě informací, tvořivě pracovat $\mathrm{s}$ informacemi a využívat je při dalším vzdělávání i v praktickém životě (RVP ZV, 2005, s. 33).“

Jak uvádí Zounek, současným trendem je ale „komplexní zavádění ICT do vzdělávacích programů (kurikula) škol, kde se využití ICT neomezuje pouze na některé předměty, ale jde „,např́ičc“ kurikulem (2006, s. 81).“ Takové využití ICT ve výuce umožňuje interaktivní tabule Předpokladem adekvátního využití interaktivní tabule je však jistá informační gramotnost, tedy „schopnost využívat moderní informační technologie a prostředky (Maněnová, 2009, s. 9).“

Informační gramotnost ve školách posuzuje několik systémů. V USA se jedná o systém ISTE (International Society for Technology in Education) a v Evropě je to EPICT (The European Pedagogical ICT Licence). Oba systémy určují, co by měl učitel ale rovněž i žák znát v oblasti ICT (Hadašová, 2011). Česká republika nepracuje podle žádného z uvedených systémů, gramotnost v oblasti ICT tedy nemůžeme spolehlivě měřit ani srovnávat. $\mathrm{O}$ jisté úrovni informační gramotnosti však vypovídají dosažené výsledky výchovně vzdělávacího procesu, jak se ukazuje i v našem předvýzkumu.

\section{Předvýzkum}

- Cíl: Cílem předvýzkumu disertační práce bylo zjistit, zda konstantní používání interaktivní tabule ve výuce matematiky na 1. stupni ZŠ může ovlivnit výsledky žáků. Naší prioritou bylo zjistit, zda existuje statisticky významný rozdíl v dosažených výsledcích didaktického testu z matematiky ve trrídě, která pracuje s interaktivní tabulí, a ve třídě vyučované bez interaktivní tabule.

- Výzkumná otázka: Jsou výsledky didaktického testu z matematiky stejné ve třídě vyučované s interaktivní tabulí a ve třídě vyučované tradičními metodami?

- Charakteristika výzkumného vzorku: Předvýzkum byl prováděn na ZŠ a MŠ Masarykovy sady, Český Těšín. Výzkumným vzorkem bylo 66 žáků prvního a druhého ročníku. Žáci 1. A (19) byli vyučováni pomocí IT, žáci 1. B (15) s interaktivní tabulí nepracují. Žáci 2. A (17) rovněž nepracují s IT, 15 žáků 2. B pracuje s IT.

- Metoda získávání dat: Data převýzkumu byla získána prostřednictvím didaktických testů ověřujících, polytematických, subjektivně skorovatelných. V didaktických testech byly předkládány otevřené úlohy se stručnou odpovědí a přiřazovací úlohy.

- Didaktický test 1: Didaktický test 1 byl vypracován vedením ZŠ a MŠ Masarykovy sady, jednalo se o srovnávací závěrečný didaktický test pro 1. ročník, který vycházel z požadavků ŠVP.

- Didaktický test 2: Didaktický test 2 byl vypracován vedením ZŠ a MŠ Masarykovy sady, jednalo se o srovnávací závěrečný didaktický test pro 2. ročník, který vycházel z požadavků ŠVP.

- Podmínky vypracování testu: Didaktické testy byly řešeny vždy 2. vyučovací hodinu, žáci byli předem upozorněni na pomůcky nutné k řešení testu, zadání testů bylo nahlas 
prezentováno, zodpovězeny byly rovněž př́ípadné nejasnosti. Žákům byl stanoven orientační limit ke zpracování didaktického testu (30 minut). Všichni žáci splnili test $\mathrm{v}$ orientačním časovém limitu.

- Použitá metodologie: K ověření hypotézy jsme použili U-test. Jedná se o statistickou metodu pro analýzu ordinálních (pořadových) dat. $\mathrm{V}$ tomto př́padě jsme použili U-test při velkých četnostech.

Statistické hypotézy:

- $\mathrm{H}_{0}$ Mezi výsledky didaktického testu $\mathrm{v}$ obou třídách nejsou rozdíly.

- $\mathrm{H}_{\mathrm{A}}$ Mezi výsledky didaktického testu v obou trrídách jsou rozdíly.

Tabulka 1 a 2

Výsledky didaktického testu 1 pro první ročníky ZŠ

\begin{tabular}{|l|l|}
\hline 1. A & \\
\hline Počet bodů & Pořadí \\
\hline 21 & 1,5 \\
\hline 21 & 1,5 \\
\hline 23 & 4,5 \\
\hline 23 & 4,5 \\
\hline 25 & 7,5 \\
\hline 27 & 12,5 \\
\hline 27 & 12,5 \\
\hline 27 & 12,5 \\
\hline 27 & 12,5 \\
\hline 27 & 12,5 \\
\hline 28 & 21 \\
\hline 28 & 21 \\
\hline 28 & 21 \\
\hline 28 & 21 \\
\hline 28 & 21 \\
\hline 29 & 30 \\
\hline 29 & 30 \\
\hline 29 & 30 \\
\hline 29 & 30 \\
\hline
\end{tabular}

\begin{tabular}{|l|l|}
\hline 1. B \\
\hline Počet bodů & Pořadí \\
\hline 23 & 4,5 \\
\hline 23 & 4,5 \\
\hline 25 & 7,5 \\
\hline 27 & 12,5 \\
\hline 27 & 12,5 \\
\hline 27 & 12,5 \\
\hline 28 & 21 \\
\hline 28 & 21 \\
\hline 28 & 21 \\
\hline 28 & 21 \\
\hline 29 & 30 \\
\hline 29 & 30 \\
\hline 29 & 30 \\
\hline 29 & 30 \\
\hline 29 & 30 \\
\hline
\end{tabular}

Po dosazení do př́slušných vzorců dostáváme hodnotu normované náhodné veličiny $|\mathbf{u}|=$ 0,88. Vypočítanou hodnotu srovnáváme $\mathrm{s}$ kritickou hodnotou $\mathrm{u}_{0,05}=1,96$ pro hladinu významnosti $\mathrm{p}<0,05$ (Chráska, 2007). Protože vypočítaná hodnota není větší než 1,96, odmítáme hypotézu alternativní a přijímáme hypotézu nulovou. Mezi výsledky obou tříd nejsou na hladině významnosti $\mathrm{p}<0,05$ statisticky významné rozdíly. I po výpočtu dle upraveného vzorce, který zahrnuje ve výpočtu hodnoty, které se opakují a ve výpočtu tak zkreslují hodnotu, není vypočítaná hodnota větší než 1,96 $\left(\left|u^{\prime}\right|=0,99\right)$. Ani zde nám hodnota nepoukazuje na statisticky významné rozdíly ve výsledcích testu. 
Tabulka 3 a 4

Výsledky didaktického testu 2 pro druhé ročníky Zঙ̌

\begin{tabular}{|l|l|}
\hline 2. A & \multicolumn{2}{|l|}{} \\
\hline Počet bodů & Pořadí \\
\hline 19 & 3,5 \\
\hline 19 & 3,5 \\
\hline 25 & 5,5 \\
\hline 26 & 8 \\
\hline 27 & 11,5 \\
\hline 27 & 11,5 \\
\hline 31 & 16 \\
\hline 33 & 17,5 \\
\hline 34 & 19,5 \\
\hline 34 & 19,5 \\
\hline 36 & 21,5 \\
\hline 37 & 23,5 \\
\hline 38 & 27 \\
\hline 38 & 27 \\
\hline 38 & 27 \\
\hline 39 & 31 \\
\hline 39 & 31 \\
\hline
\end{tabular}

\begin{tabular}{|l|l|}
\hline 2. B & \\
\hline Počet bodů & Pořadí \\
\hline 18 & 1,5 \\
\hline 18 & 1,5 \\
\hline 25 & 5,5 \\
\hline 26 & 8 \\
\hline 26 & 8 \\
\hline 27 & 11,5 \\
\hline 27 & 11,5 \\
\hline 30 & 14,5 \\
\hline 30 & 14,5 \\
\hline 33 & 17,5 \\
\hline 36 & 21,5 \\
\hline 37 & 23,5 \\
\hline 38 & 27 \\
\hline 38 & 27 \\
\hline 39 & 31 \\
\hline
\end{tabular}

Po výpočtu testového kritéria a dosazení do vzorce dostáváme hodnotu normované náhodné veličiny $|\mathrm{u}|=0,89$. Vypočítanou hodnotu opět srovnáváme $\mathrm{s}$ kritickou hodnotou $\mathrm{u}_{0,05}=1,96$ pro hladinu významnosti $\mathrm{p}<0,05$. Protože vypočítaná hodnota rovněž není větší než 1,96 , odmítáme hypotézu alternativní a přijímáme hypotézu nulovou. Mezi výsledky obou tříd nejsou na hladině významnosti $\mathrm{p}<0,05$ statisticky významné rozdíly. I zde po výpočtu dle upraveného vzorce, který zahrnuje ve výpočtu hodnoty, které se opakují a ve výpočtu tak zkreslují hodnotu, není vypočítaná hodnota větší než $1,96\left(\left|\mathbf{u}^{6}\right|=0,89\right)$. Hodnota tedy opět nepoukazuje na statisticky významné rozdíly ve výsledcích testu.

\section{Závěr}

Výsledky předvýzkumu (srov. tab. 1-4) považujeme za velmi uspokojivé. Poukazují totiž na to, že práce $\mathrm{s}$ interaktivní tabulí je plnohodnotnou alternativou tradičních metod výuky s komparabilními výsledky výchovně vzdělávací práce. Rezultát výzkumu rovněž odhalil, že učitelé vykazují velmi uspokojivou úroveň informační gramotnosti, která se projevila právě ve statisticky nevýznamných rozdílech ve výsledcích didaktického testu ve srovnávaných tř́dách. Uvědomujeme si, že vybraný vzorek respondentů je nedostačující. Pro objektivní výsledky testu by bylo zapotřebí testovat nejméně 400 respondentů. To je ale zcela nemožné v př́ípadě, kdy hledáme souběžné třídy, kde jedna je vyučována s interaktivní tabulí a druhá bez použití tohoto zařízení. Další možností pro dosažení objektivity výsledků je použití standardizovaných testů. V současné době vzhledem k probíhající kurikulární reformě ale neexistují standardizované testy z matematiky pro jednotlivé ročníky. V novém školním roce 
se mají ověřovat první standardizované testy pro páté ročníky primárních škol. V další fázi našeho výzkumu tedy předpokládáme využití těchto testů.

\section{Literatura}

Hadašová, K. (2011). Využití interaktivni tabule v matematice (Diplomová práce). Dostupné z http://is.muni.cz/th/209412/pedf_m/verzekonecna.pdf

Chráska, M. (2007). Metody pedagogického výzkumu: základy kvantitativního výzkumu. Praha: Grada. Maněnová, M. (2009). Učitel primárního vzdělávání ve vztahu k ICT. Hradec Králové: Gaudeamus. Zounek, J. (2006). ICT v životě základnich škol. Praha: TRITON.

Rámcový vzdělávaci program pro základni vzdělávání. (2005). Praha: VÚP v Praze.

Šed’ová, K., \& Zounek, J. (2009). ICT v rukou českých učitelů. Pedagogika, 59(1), 54-70.

\section{Kontakt}

Mgr. Veronika Švrčinová

Univerzita Palackého v Olomouci

Pedagogická fakulta, Katedra primární pedagogiky

Žižkovo nám. 5, 77140 Olomouc

e-mail: chavercha@ seznam.cz

\section{Bibliografické údaje}

Švrčinová, V. (2011). Výuka s interaktivní tabulí versus tradiční výuka v primární škole. In T. Janík, P. Knecht, \& S. Šebestová (Eds.), Smíšený design v pedagogickém výzkumu: Sborník př́spěvků z 19. výročni konference České asociace pedagogického výzkumu (s. 500-504). Brno: Masarykova univerzita.

Dostupné z: http://www.ped.muni.cz/capv2011/sbornikprispevku/svrcinova.pdf

doi: 10.5817/PdF.P210-CAPV-2012-75 